\title{
Editorial
}

\section{A recognition of integration and synergy}

\section{A TIME FOR CHANGE}

Three years ago the Journal of Leisure Property was launched. It was a clear and tangible recognition that the market for leisure property had developed to a point where it needed an international arena in which all those active in the area could disseminate their innovations and knowledge, thereby provoking discussion and debate and leading the industry forward. The Journal was successful in its mission and within its three volumes many aspects of leisure developments, from funding to planning to operational requirements, were considered. However, the Journal always recognised that the leisure property market does not exist within a vacuum. More than any other forms of commercial property development, successful leisure schemes must take account of the needs of the operator. If they do not, commercial success simply will not happen. Value, brand and management are inextricably linked together, and good design that is sensitive to this is required.

Accordingly, the Journal contained several papers that articulated the relationship with other property types - notably retailing. In this the Journal was recognising how the focus of developments has shifted over time, and so the decision was taken to widen the Journal's scope and rename it the Journal of Retail \& Leisure Property. The title now explicitly recognises the synergy that exists between retailing and leisure within city centres in both the UK and many other parts of the world.

\section{THE SYNERGY BETWEEN RETAIL AND LEISURE WITHIN PROPERTY DEVELOPMENTS}

The connection between retailing and leisure may seem obvious to readers of this Journal and it is easy to forget just how fast and how far change has occurred. The concept of mixed-development schemes in which leisure property sits alongside retail outlets is now so well accepted as a development format within the UK that it seems hard to remember just what a recent phenomenon it is. Yet it was little more than a decade ago that the English Tourist Board and then-named Jones Lang Wootton first argued for a synergy between retail and leisure that should be reflected in property terms. ${ }^{1}$ At that time leisure units were considered to be unacceptable to institutional investors - almost on principle! ${ }^{2}$ Any developer seeking funding was very unlikely to find institutions 
willing to take what was perceived to be an unacceptable risk. Hence the leisure property sector, unlike the retail and office markets, was, for the most part, dominated by owner-occupation. This was despite the fact that leisure developments represented an opportunity for investors, as well as operators, to tap into a sector of the economy that had outperformed others fairly consistently over a number of years. ${ }^{3}$

The reluctance at that time to invest in leisure was not just born of risk; a lack of suitable supply and a lack of knowledge of how the leisure market worked among both the investment and development community also presented real barriers. By the late 1990s a very different scenario prevailed with a rash of innovative schemes coming forward, many of which were anchored on multiplex cinemas. These soon began to gain institutional acceptance, with MWB's first leisure fund quickly being fully subscribed. The result was that the leisure sector - or at least some parts of it - became realigned in terms of acceptability and value.

But the type of schemes has continued to evolve. From standalone leisure and retail schemes to integrated schemes such as the award-winning Gunwharf Quays in Portsmouth and the imaginative chain of Heron Cities that have been developed in Spain and elsewhere, the innovation has continued. One of the most remarkable changes has been that whereas, in early integrated schemes, leisure (usually in the form of food and drink outlets) was viewed as an adjunct or added extra within a scheme - something to provide a service to shoppers and help to extend the duration of each visit - now it is integrated completely as an equal-valuecreation element.

Furthermore, it is not just integration within the scheme that is now sought. There is recognition that towns and cities are being redefined in terms of their role. With greater opportunities for ecommerce people use buildings differently - there is a rediscovery of the town as a locus for social as well as business activity. This requires that schemes do not just look inward upon themselves but see and build upon their physical context. Anthony Walker, writing in this issue about the award-winning and recently opened scheme The Light in Leeds, forcefully makes this point. He argues that 'The Light is the very opposite of the traditional shopping centre or urban entertainment centre, in that unlike the usual inward-looking block with limited entrances and outlook, this building not only invites the city into its heart but also actively faces outward to interact with its surroundings.'

As town centres evolve, the leisure pound and the retail pound become even more inextricably linked. But, it is useful to bear in mind the analysis undertaken by $\mathrm{Cox},{ }^{4}$ who argues that shopping is a continuum of activities from the 'purposeful' to the 'browsing leisurely shop' to the full-blown entertainment motivation. Ives in this issue brings out the fact that retailers are responding to this in his useful and insightful review of retail property development 
trends in the Central London market. In his analysis, the slowing UK economy may have slowed demand and increased competition but it has also seen innovation in the offers retailers devise to respond to a generation used to pursuing 'wants' rather than 'needs'.

Both these papers make clear that the distinction between retail and leisure activity is becoming ever more blurred. This needs to be recognised in the land-use planning system. The fact that it is not can lead to conflict of the type most clearly demonstrated in Frost's paper in this issue on the UK property market for pubs, bars and restaurants. By a case study of Westminster he details the potential - and actual - problems and conflicts that can arise between residents and operators as the leisure/retail economy grows. In his conclusion he calls for the government to recognise this as they undertake planning reforms that are promoted as the most wideranging changes in over half a century. Unfortunately, as at the time of writing, the draft legislation does not adequately address these issues. It is hoped - at least by your Editor — that some details as to how the currently broad-brush legislation will be developed at the operational level in respect of retail and leisure development.

\section{TOWARDS A WIDER REMIT FOR THE JOURNAL}

One change that is noticeable with the broadening of the remit is that the Journal is now able to accept papers on a wider range of topics. For this reason Lakis Pavlou's paper in this issue on the contribution of the first 25 years of retail warehousing to the retail sector is particularly welcome. There surely can be little doubt that the advent of the retail warehouse, itself a product of greater car and home ownership, has had a very significant effect on the way in which retail operates. Indeed, it has contributed to the changing role of town centres as they lost ground during the 1980s and early 1990s to out-of-town and edge-of-town locations, initially for bulk goods. Pavlou picks up on recent planning decisions that indicate ever more strict interpretation of PPG6. ${ }^{5}$ In light of this, he argues that the emphasis may switch at lease expiry towards 'recycling' and intensification of use of existing sites offering choice within the same goods class. His judgment that the moves will be positive and lead to greater consumer choice is something that surely will be debated in future Journal contributions!

So much for some of the UK domestic large-scale issues that affect the retail and leisure markets. Successful property management and investment depends as much on getting the legal detail right as on creating the building appropriately. For this reason, the appointment of Geoffrey Silman as the Section Editor for the subject of leases is very welcome. In his first contribution, Silman gives a thorough analysis of the recent UK case, Allied Dunbar Assurance plc v Homebase Limited and Another (2002), and points out how long leases can give rise to many pitfalls to tenants 
in times of poor market conditions as they seek to shed space. This case has caused considerable concerns among business occupiers. Given the length of the leases which many multiplex cinema and other leisure anchor tenants hold and the stringent conditions of those leases, there may be good cause for such companies to heed the advice given at the end of the analysis!

\section{WIDER ISSUES IN RETAIL AND LEISURE: THE INTERNATIONAL PERSPECTIVE}

In widening the Journal's scope the international angle has not been ignored, nor has the hospitality angle of leisure. Two papers on aspects of hotels ensure these dimensions continue to be addressed, together with one on franchising. Both the paper by Brian Tress and that by Bill Bissell and Chuck Bedsole give clear and practical advice in relation to the hotel trade, while Martin Camp gives some practical pointers on retail refranchising deals. Tress picks up on the key role that hotel and conference trade facilities can have in stimulating urban regeneration. For this public sector finance is normally required to seedcorn private investment monies, and his paper details ways in which a constructive and open approach to the use of public-private partnerships can be the key to unlocking development potential.

The theme of partnership is also taken up by Bissell and Bedsole, but within a different context - that of the emerging Mexican market. They conclude that the market in Mexico has much to offer. It is currently underexploited, yet the country has enormous natural attractions and a favourable investment climate and cost structures. These factors, together with its proximity to the USA, are all encouraging signals to inward investment in hospitality and tourism. But the legal context is complex, and for this reason they advocate partnering with local development organisations and teams who can do much to ensure that the development can proceed to time and budget.

\section{TOWARDS THE FUTURE}

The Journal has developed to be aligned to emerging needs within the retail and leisure sector. To assist in this an Editorial Board and Section Editors have been appointed, including a wide cross-section of operators, developers and consultants, to ensure that expertise exists to support all contributors and a lively and informed debate can take place through its pages. With informed and thoughtprovoking contributions, the ambition is that a deeper understanding can be obtained of the role of retail and leisure property within both individual portfolios and the wider economy.

Sarah Sayce May 2003 


\section{References}

1. English Tourist Board and Jones Lang Wootton (1989) Retail, Leisure and Tourism, Jones Lang Wootton, London.

2. Sayce, S. (1993) 'Leisure property: For and against', paper presented to the Henry Stewart Institutionally Acceptable Property Conference.

3. Figures from the Office for National Statistics reveal that leisure spend, notably on urban entertainment, has been a steadily increasing percentage of domestic spending.

4. Cox, J. (2001) 'What counts in leisure property?' paper presented to a Leisure Property Forum seminar, London, January.

5. PPG6 (Planning Policy Guidance note 6) introduced in the mid-1990s the 'sequential test' under which the preferred location for commercial developments was to be town centres in order to protect their viability. Only in the event of proven non-availability of sites will edge-of-town or out-of-town locations be allowed. 